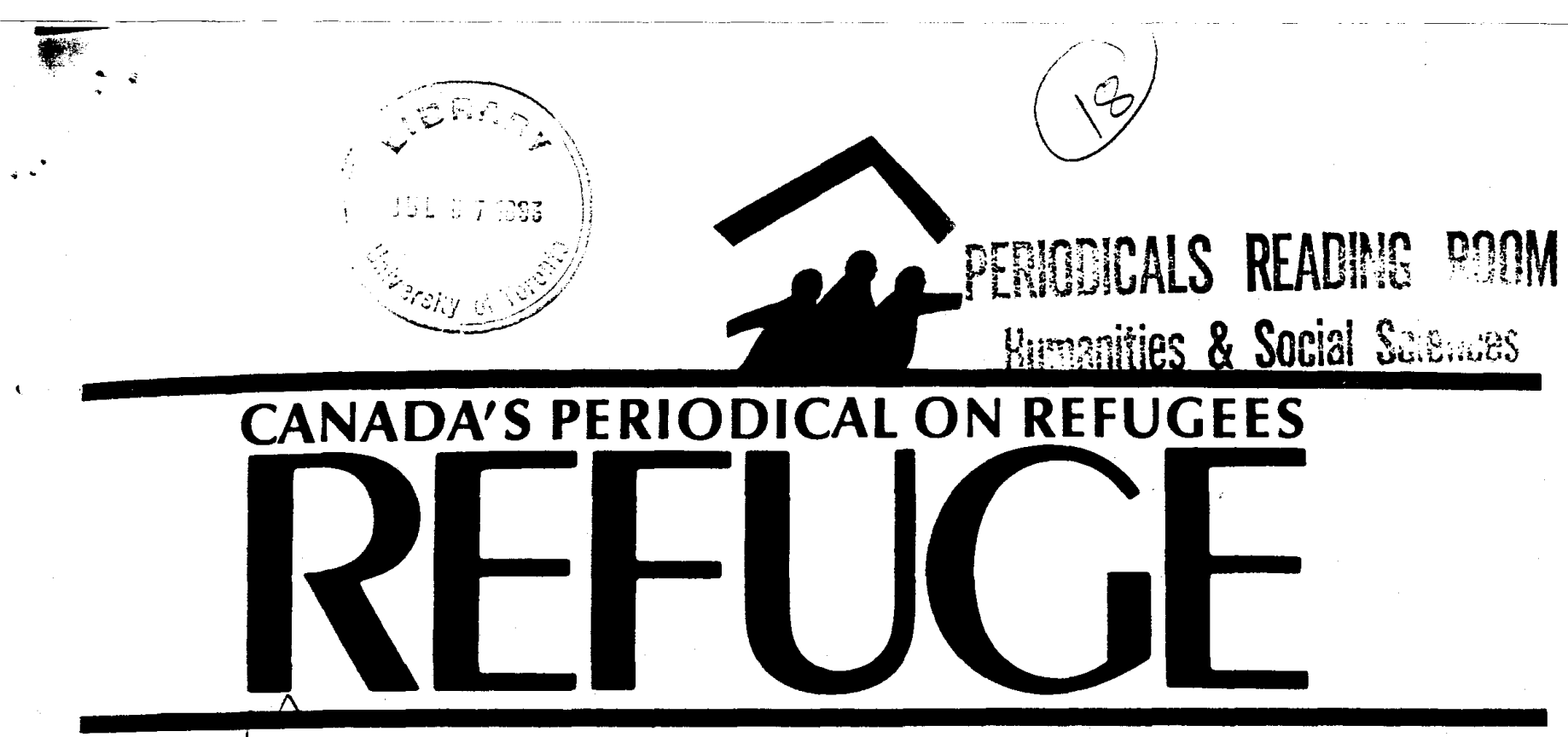

Vol. 8, No. 1

October 1988

\title{
Refugees and the Elections
}

Will refugees be an issue in the forthcoming election on November 21st?

There is no factious debate in Canada over the treatment of humanitarian rcfugees - those refugees, largely in refugee camps, that our immigration officials select abroad as designated class immigrants for admission under reduced criteria. They make up the bulk of our refugee admissions.

There are those who believe the government should sponsor more humanitarian refugees. Others on the political spectrum oppose the admission of these refugees (as in the Nielsen Report). Nevertheless, there is a general consensus of support for the present policy among the parties and among refugee support groups.

This does not mean that valid arguments are not made for an increase in the total intake. Further, some would prefer a slightly different distribution of the intake. But the option to increase the total numbers and to target spccific refugees through private sponsorship defuses any opposition.

- The only serious flaw in the whole system of aid to humanitarian refugees, the lack of government personnel in the field, results in long delays before privately sponsored refugees arrive. A serious but relatively minor problem, but not an election issue.

The Mulroney government is to be congratulated for continuing and enhancing the Canadian tradition of offering resetllement opportunities to refugees selected abroad. This is particularly commendable given some of the attitudes within its own party as evidenced by the Nielsen Report prepared shortly after the Mulroney Tories took power.

But what about those who arrive in Canada and claim to be Conoention refugees? Has the current government been responsive to their needs?

First, the problem did not begin with the Tories; they inherited a large backlog of refugee claimants. Second, the previous government set up one study after another and failed to come up with a solution. The last commission set up by the Liberals, that of Rabbi Plaut, reported shortly after the new government took power. The new government took half of its period in office to decide to ignore the spirit of the Plaut Report (which focused on a faster and fairer system for processing claims) and to introduce new legislation largedly focused on deterring claims and reducing the numbers entering the claims system.

That legislation took the balance of the government's term to pass and set up the implementing agencies. It will only become operational when the new govern- ment takes power.

On the one hand, the refugee claims backlog has tripled. On the other hand, the government did decide to do something about it. They did introduce enabling legislation and set up the appropriate machinery.

Critics fault these actions and other inactions, on five grouds. First, the new legislation is allegedly motivated by antirefugee sentiment. Second, critics claim the legislation is unfair; genuine refugees may be denied access to the claims process. Third, nothing has been done about the huge backlog of claimants; nor will the new machinery affect those claimants. Fourth delays in refugees obtaining work permits have grown much longer with consequent further disruptions in their lives and tremendous cost to the welfare system in Canada. Finally, in addition to criticizing the government for its bad motives, the potential unjust consequences of the new legislation, the ineffectiveness in dealing with past backlogs, and effectiveness in adding to the welfare rolls, the Tories are

\section{IN THIS ISSUE:}

The Immigration and Refugee Board

page 3

The Mouse that Roared by Howard Adelman

page 4

Who's Who in C.E.I.C. - Ottawa

page 9

Review: Journal of Refugee Studies by C. Michael Lanphier 
accused of using the new Refugee and Immigration Board as a golden opportunity to make a large number of patronage appointments.

Criticizing the Mulroney government for anti-refugee motives is unfounded. When the Sikhs arrived by boat off the Newfoundland coast, the Mulroney government was effusive in expressing its support for refugees and went beyond the call of duty (and, perhaps, prudence) in the speed with which ministerial permits were issued. Further, if the government had been anti-refugee, the Minister of Immigration and Employment would not have made an open and unqualified promise not to designate a country as "safe" for a group of refugee claimants if that country had a bad record in processing refugee claims from that group. The speed and the content of the legislation cannot be attributed to an anti-refugee motive.

The government can be accused of bad motives - of pandering to the antirefugee and/or anti-Asian attitudes still prevalent in Canada. Evidently, the backlash from the Sikh arrival and the Tamil

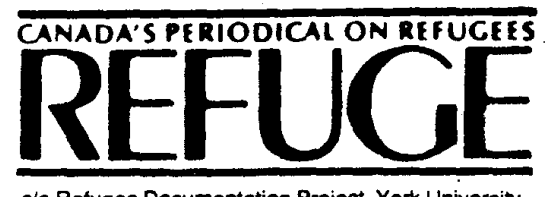

c/o Refugee Documentation Project, York University 4700 Keele Street, North York, Ontario M3J 1 P3

Editor:

Howard Adelman

Executive Editor:

Alex Zisman

Refuge is dedicated to the encouragement of assistance to refugees by providing a forum for sharing information and opinion on Canadian and international issues pertaining to refugees. It is published four times a year by the Refugee Documentation Project. It is a non-profit, independent periodical supported by private donations and by subscriptions. It is a forum for discussion, and the views expressed do not necessarily reflect those of its funders or staff.

All materials in Refuge may be reproduced without permission unless copyrighted or otherwise indicated. Credit should be given to the author or source, if named.

Subscription rates for one year are $\$ 20.00$ in Canada and US $\$ 25.00$ overseas. Please enclose payment with your order.

Logo design:

Dreadnaught Co-operative Inc., Toronto

Second Class Mail Reg istration No 5512 ISSN 0229-5113 arrival one year later off our eastern seaboard was virtually unprecedented. The new legislation caters to that backlash, but, ironically, without significantly affecting the numbers who will arrive or be processed by the claims system.

The critics are correct in alleging the new legislation has the potential to be unjust to some genuine refugees. But this is a possibility and not an actuality. Until and unless there is demonstrable proof that genuine refugees have, in fact, been sent back to their home countries where they have been persecuted, the critics will not have much ammunition.

The government can be criticized for not dealing with the current backlog and for adding to the high costs of tax payers in prolonging the refugee claimant's period on welfare because of delays in allowing the refugee claimants to obtain work permits.

But there are other grounds for criticizing the ineffectiveness of the legislation. It will do little to dent the large numbers of refugee claimants entering the system (see this issue of Refuge - "The Mouse that Roared"). The numbers of claimants will grow. The backlog will grow. And the issue of spontaneous arrivals claiming refugee status will remain a tot topic on the political agenda. And more positions will be opened up for patronage appointments to the Refugee Board.

Was this really the purpose of the legislation - to provide jobs for Tory straphangers? Though Gordon Fairweather, who heads the whole board, is a Tory, he has an impeccable record of concern for human rights issues. On the other hand, many of the appointees have strong Tory, and, particularly, Mulroney ties. Other appointees are clearly commendable. A large number come from ethnic groups, perhaps indicating the Tory government is intent on displacing the assumed Liberal monopoly on the loyalty of ethric voters, though there is a striking gap in the numbers of appointees who come from Central and South American countries.

The new legislation has enabled the Mulroney government to mix patronage and political strategy in its appointments with a semblance of fairness and judicious commitment.

Our criticism focuses elsewhere - on assumptions. The new system will be costly. It will not do what it was intended to do - reduce significantly the number of refugee claimants. And the reason is one of false premises. There are policy makers largely civil servants - who are committed to the view that Canada is a country of immigration and not a country of asylum. They are convinced we must select who comes here. Spontaneous arrivals, whether legitimate refugees or not, should be deterred. We must return to the "good old days" when spontaneous arrivals made up an insignificantly small portion of our refugee intake.

However, we have become a country of first asylum, whatever the route refugees use to arrive here. We will remain a country of first asylum. We will continue to have large - and even larger - numbers of spontaneous arrivals. And any system of legislation should focus on that reality instead of a fantasy about Canada. The system should stress both speed of processing and fairness to the refugees - not deter-. rence.

Deterrence is going to be very costly to the taxpayers. Deterrence is going to be ineffective in reducing the number of claimants significantly. Failed deterrence measures are going to keep the refugee issue on the frorit pages and add to antirefugee sentiment.

Yet, the refugee issue will not become a significant election issue. It is not simply that the new legislation is too new and, as yet, untried. Nor is it that the Canadian public must decide on the implications of the U.S. free trade agreement on the future of Canada, an issue putting all others into the shadows. For nothing is more central to Canada than who we allow to become members of our Canadian community and the processes adopted to permit membership.

The major reason for the refugee issue not becoming an election issue is the wcakness of the pro-refugee lobby and the somnolence of the anti-refugee lobby lulled into contentment by the now legislation. The pro-refugee lobby showed, when the legislation was first introduced, that it had not developed widespread grass roots committed support which could be activated to write large numbers of letters. And, if the pro-refugee lobby was so uniformly and adamantly opposed to the new legislation, the anti-refugee lobby probably erroncously concluded that the legislation favoured their position.

Finally, elections, as currently conducted, are not the best opportunities for rational debate on fundamental issues. Superficial treatment, the importance of the leader, and the potential for non-rational factors to grab the spotlights, mitigate against using elections to debate the fundamental premises of Canadian society. We await the new parliament to continue the debate.

Howard Adelman, Editor 